九州大学学術情報リポジトリ

Kyushu University Institutional Repository

\title{
Habitat Features of Dwarf Loach, Kichulchoia brevifasciata (Pisces: Cobitidae) from Korea in a Conservative Perspective
}

Kim, Eun-Jin

Institute for Biodiversity, Chonbuk National University

Kim, Ik-Soo

Institute for Biodiversity, Chonbuk National University

Mochioka, Nor i taka

Animal and Marine Bioresource Science, Bioresource Sciences, Faculty of Agriculture, Kyushu University

https://doi.org/10.5109/22054

出版情報：九州大学大学院農学研究院紀要. 57 (1)，pp.87-91，2012-02. Faculty of Agriculture， Kyushu University

バージョン :

権利関係 : 


\title{
Habitat Features of Dwarf Loach, Kichulchoia brevifasciata (Pisces: Cobitidae) from Korea in a Conservative Perspective
}

\author{
Eun-Jin KIM*, Ik-Soo KIM ${ }^{1}$ and Noritaka MOCHIOKA \\ Laboratory of Fisheries Biology, Faculty of Agriculture, \\ Kyushu University, Fukuoka, 812-8581, Japan \\ (Received October 31, 2011 and accepted November 9, 2011)
}

\begin{abstract}
The small cobitid fish Kichulchoia brevifasciata, a Korean endemic found in the extreme southwestern part of the Korea, lives in small streams of $5 \sim 65 \mathrm{~cm}$ in depth, with pebble bottoms with some sands and slow water currents. The habitat is shared with Zacco koreanus, Rhynchocypris oxycephalus, Rhinogobius brunneus, Liobagrus mediadiposalis, Misgurnus anguillicaudatus, Gymnogobius urotaenia and Tridentiger brevispinis. A mark and recapture experiment showed that the population density is $11.1 / \mathrm{m}^{2}$ in the major habitat. Habitat destruction and stream modification are major threats to the continued existence of the species. Special protection status as an endangered species is urged, with special emphasis on habitat conservation and local conservation awareness.
\end{abstract}

Key words: conservation, ecology, habitat, population

\section{INTRODUCTION}

The small cobitid fish Kichulchoia brevifasciata, a Korean endemic, is restricted to localities in Jeollanam-do in the extreme southwestern part of Korea (Fig. 1), reported as Yamak-li, Pungyang-myeon, Goheung-Gun; Okang-li, Podu-myeon, Goheung-gun; Nam-myeon, Yeosu-si; Geumsan-myeon, Goheung-gun (Kim and Lee, 1995; Kim, 1997; Kim and Kim, 2008).

Following its initial description as a new species (Kim and Lee, 1995), K. brevifasciata has been included in both molecular phylogenetic studies (Kim et al., 2000; Šlechtová et al., 2008) and karyotype analysis (Kim and Kim, 2008), in addition to confirmation of its known distribution (Chae and Yoon, 2007).

The species inhabits small shallow water streams with gravel beds and low water currents (Kim and Kim, 2008; Kim, 2009). However, specific habitat details have not been reported. It is clear that the habitat of $K$. brevifasciata is very limited in extent supporting only a very small population in southwestern Korea at the present time (Kim, 2009). Despite the serious risk of extinction arising from future habitat degradation, K. brevifasciata is not still designated as an endangered species (Ministry of Environment, 2008). Therefore, the purpose of the present study aimed to determine habitat features and population size of $K$. brevifasciata, thereby providing data for a conservation plan for the species.

\section{MATERIALS AND METHODS}

The habitats of Kichulchoia brevifasciata have

${ }^{1}$ Institute for Biodiversity, Chonbuk National University, Jeonju, 561-756, Jeollabuk-do Prov., Korea; e-mail: kim9620@ chonbuk.ac.kr

* Corresponding Author: Eun-Jin KIM (E-mail: jaurlim@agr. kyushu-u.ac.jp been listed as four points (Kim and Lee, 1995) (Fig. 1), as Yamak-li, Pungyang-myeon, Goheung-Gun, Jeollanam-do; Okang-li, Podu-myeon, Goheung-gun, Jeollanam-do; Nam-myeon, Yeosu-si, Jeollanam-do; Geumsan-myeon, Goheung-gun, Jeollanam-do, were examined to confirm whether $K$. brevifasciata is existent or not in the present. In addition, environmental factors surrounding the habitats were investigated from four points, such as dissolved oxygen (DO), $\mathrm{pH}$, conductivity (a measure of water quality) with any modification of the habitats by artificial construction for comparison with present habitat conditions in thought to be relatively stable environment of the stream from April to June 2006 monthly.

From the results in this survey of the four points, a small stream in Geumsan-myeon, Goheung-gun, Jeollanam-do currently confirmed existence of the $K$. brevifasciata was examined mainly again to acquire detailed information as the main habitat conditions. Air temperature and water temperature, were measured at the end of the month from January 2006 to May 2007 in an identified habitat of large individuals of $K$. brevifasciata. The individuals were confirmed from upstream to downstream, but mid-stream, covered with only some large rocks and water flow was sometimes disconnected about $1 \mathrm{~km}$ flowing to under the river bed, was not included the analysis of the stream features for the benthic fish, $K$. brevifasciata. The stream characteristics between upstream and downstream were examined in May 2007 including water width and depth (measured by tapeline), water velocity (tachometer, global water instrumentation) stream shape (Kani, 1944) and stream bed type (Cummins, 1962). Upstream, mid-stream and downstream fish fauna were sampled monthly from May 2006 to May 2007 and collected individuals calculated as the percentage of the average population.

Mark and recapture experiments were attempted at a number of sites. However, most returned limited num- 
bers of fish (less than 20 captured per month) and habitat disruption due to low and intermittent water flow, sometimes disrupted for up to $1 \mathrm{~km}$, became problematic. Then after certain attempts, a mark and recapture experiment was performed successfully from April 23, 2007 to May 7, 2007 at a restricted site at the upper end of the major habitat, prior to the spawning and rainy seasons.

Sampling was conducted for 2 hours at each visit on a suspected isolated population in an area of favored stream habitat $(50 \mathrm{~m} \times 3 \mathrm{~m})$. Each adult individual captured ( $>40 \mathrm{~mm}$ in TL) was marked on the initial capture by clipping the right ventral fin whilst anesthetized and subsequently released unharmed at the point of capture. Estimation of the population size followed Chapman (1951) and Seber (1970), being suitable for low sample sizes. The expected population size (determined from the first and second visits) was calculated as follows:

$$
N=(M+1)(C+1) /(R+1)-1
$$

where $N$ is the estimate of total population size, $M$ is the total number of individuals captured and marked on the first visit, $C$ is the total number of individuals captured on the second visit, and $R$ is the number of individuals captured on both visits.

\section{RESULTS}

\section{Recent changes in habitat conditions to the present day}

At the time of its initial description, Kichulchoia brevifasciata was more or less broadly distributed in southwestern Korea, including Goheung-gun and Yeosu-si, Jeollanam-do (Fig. 1) (Kim and Lee, 1995).

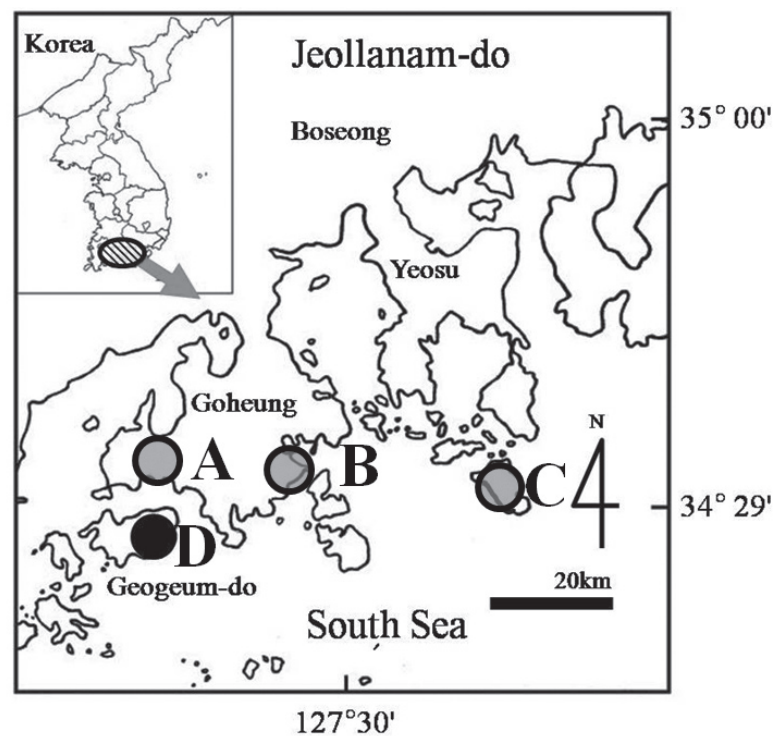

Fig. 1. Map of sites examined for populations of Kichulchoia brevifasciata (all in Jeollanam-do, Korea).

A, Yamak-li, Pungyang-myeon, Goheung-Gun; B, Okangli, Podu-myeon, Goheung-gun; C, Nam-myeon, Yeosu-si; D, Geumsan-myeon, Goheung-gun.
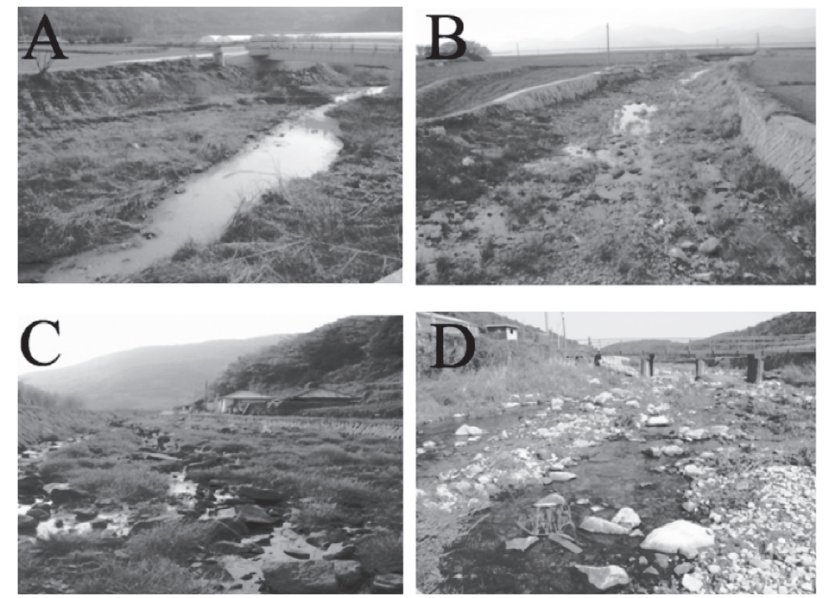

Fig. 2. Present (D) and former (A, B and C) habitats of Kichulchoia brevifasciata.as in Fig. 1.

Table 1. Physical data from April to June 2006 for present and former habitats of Kichulchoia brevifasciata

\begin{tabular}{cccc}
\hline Localities & $\begin{array}{c}\mathrm{DO} \\
(\mathrm{mg} / \mathrm{L})\end{array}$ & $\begin{array}{c}\mathrm{pH} \\
(\mathrm{mol} / \mathrm{L})\end{array}$ & $\begin{array}{c}\text { Conductivity } \\
(\mathrm{qs} / \mathrm{cm})\end{array}$ \\
\hline A & $8.5 \pm 0.3$ & $7.3 \pm 0.2$ & $114.3 \pm 2.8$ \\
B & $8.1 \pm 0.3$ & $7.1 \pm 0.2$ & $85.6 \pm 3.3$ \\
C & - & - & - \\
D & $9.4 \pm 0.2$ & $6.9 \pm 0.1$ & $81.3 \pm 2.7$ \\
\hline
\end{tabular}

A: Yamak-li, Pungyang-myeon, Goheung-Gun, Jeollanam-do, Korea; B: Okang-li, Podu-myeon, Goheung-gun, Jeollanamdo, Korea; C: Nam-myeon, Yeosu-si, Jeollanam-do, Korea; D: Geumsan-myeon, Goheung-gun, Jeollanam-do, Korea

However, the present survey confirmed individuals only in one small stream at Geumsan-myeon, Goheung-gun (Fig. 1-D and Fig. 2-D). Geumsan-myeon, Goheunggun (Fig. 2-D), where K. brevifasciata still maintains relatively stable populations, having better clear water quality $(9.4 \pm 0.2 \mathrm{mg} / \mathrm{L}$ in DO and $81.3 \pm 2.7 \mathrm{qs} / \mathrm{cm}$ in conductivity) than the other sites (Fig 2-A and B), where $K$. brevifasciata are no longer found (Table 1).

A former $K$. brevifasciata habitat at Yamak-li, Pungyang-myeon, Goheung-Gun (Fig. 1-A and Fig. $2-\mathrm{A}$ ) is populated by an exotic species (American bull frog, Rana catesbeiana), the stream having been severely modified by cement concrete construction and a factory constructed upstream from April to June 2006.

\section{Major habitat features}

The stream at Geumsan-myeon was about $4.5 \mathrm{~km}$ in length, the main habitat of $K$. brevifasciata being located about $3.5 \mathrm{~km}$ from the stream mouth. Lower stream width varied between 1.5 (winter) 16 m (summer), with a depth of $13 \sim 65 \mathrm{~cm}$ and water velocity of $0 \sim 6.5 \mathrm{~cm} / \mathrm{sec}$. Upper stream width varied between 0.5 and $3.5 \mathrm{~m}$, depth between $5 \sim 18 \mathrm{~cm}$ and water velocity from $0 \sim 3.7 \mathrm{~cm} / \mathrm{sec}$ (Table 2). The overall stream was classified as Aa, following Kani (1944), becoming Aa-Bb towards the stream mouth. Monthly air and water temperatures are given in Fig. 3, the highest recordings (in 
Table 2. Stream characteristics in the main habitat of the Kichulchoia brevifasciata studied in Geumsanmyeon, Goheung-gun, Jeollanam-do, Korea in May 2007

\begin{tabular}{cccccc}
\hline & $\begin{array}{c}\text { Water width } \\
(\mathrm{m})\end{array}$ & $\begin{array}{c}\text { Water depth } \\
(\mathrm{m})\end{array}$ & $\begin{array}{c}\text { Water velocity } \\
(\mathrm{cm} / \mathrm{sec})\end{array}$ & Stream form & $\begin{array}{c}\text { Bottom structure (\%)* } \\
\text { (B:C:P:G:S })\end{array}$ \\
\hline Upstream & $0.5 \sim 3.5$ & $0.05 \sim 0.18$ & $0 \sim 3.7$ & $\mathrm{Aa}$ & $10: 20: 20: 20: 30$ \\
Downstream & $1.5 \sim 6.0$ & $0.13 \sim 0.65$ & $0 \sim 6.5$ & $\mathrm{Aa}-\mathrm{Bb}$ & $10: 10: 20: 30: 30$ \\
\hline
\end{tabular}

* Following Cummins (1962): B (boulder, 256 mm); C (cobble, 256 64 mm); P (pebble, $64 \sim 16 \mathrm{~mm}$ ); G (gravel, 16 2 mm); S (sand, $2 \mathrm{~mm}$ )

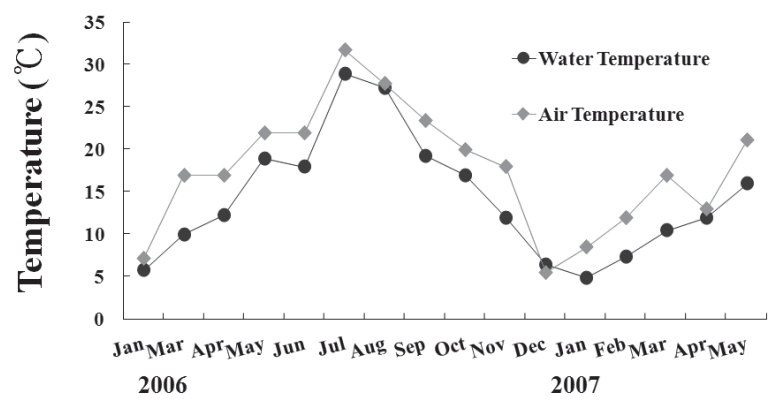

Fig. 3. Monthly changes in air and water temperatures from January, 2006 to May, 2007 in Geumsan-myeon, Goheung-gun, Jeollanam-do, Korea.

July 2006) being $31.8^{\circ} \mathrm{C}$ and $29.1^{\circ} \mathrm{C}$, respectively, and the lowest, $5.5^{\circ} \mathrm{C}$ (in December 2006) and $4.9^{\circ} \mathrm{C}$ (in January 2007), respectively. After inundation during the summer, all channels of the stream were temporarily covered by an algal bloom of the genus Spirogyra.

Observations of active $K$. brevifasciata were made between March and November 2006 (in air and water temperatures $>10^{\circ} \mathrm{C}$, adults being located under or between pebbles and gravel, but not in sand-dominated habitat (Figs. 4 and 5). The hibernation period was regarded as from December 2006 to February 2007 (in air and water temperatures $<10^{\circ} \mathrm{C}$ ). During the hibernation period, the water level in the main habitat area was lowered drastically, a very few inactive individual $K$. brevifasciata with empty stomachs being located deep in the substrate.

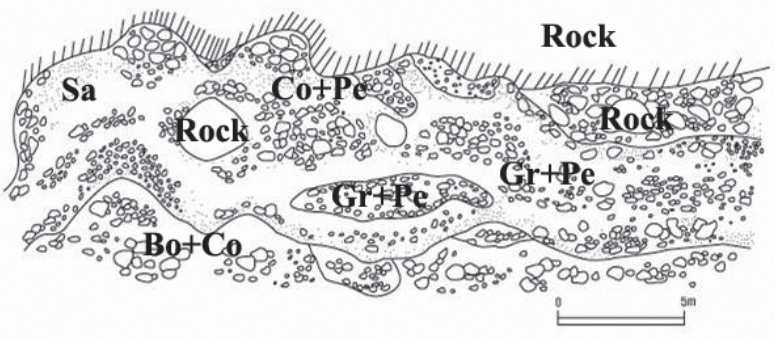

Fig. 5. Diagrammatic representation of substratum types in main habitat of Kichulchoia brevifasciata in Geumsan-myeon, Goheung-gun, Jeollanam-do, Korea.

Sa: sand; Gr: gravel; Pe: pebble; Co: cobble; Bo: boulder

The spawning season of $K$. brevifasciata extended from May to July 2006, in water temperatures between $19^{\circ} \mathrm{C}$ and $29^{\circ} \mathrm{C}$. Juveniles (10 20 mm SL) were observed from August 2006 near the banks of the upper stream in low water velocity or inside the algal beds of the genus Spirogyra.

Other fishes present in the stream included Zacco koreanus (endemic) (relative abundance 31.3\%), Rhynchocypris oxycephalus (20.5\%), Rhinogobius brunneus (18.4\%), Liobagrus mediadiposalis (endemic) (12\%), Misgurnus anguillicaudatus (1.1\%), Gymnogobius urotaenia (0.8\%) and Tridentiger brevispinis (0.1\%) (Fig. 6), the relative abundance of K. brevifasciata was $16.0 \%$. L. mediadiposalis shared similar habitat with $K$. brevifasciata although in shallow, higher velocity waters. The former disappeared
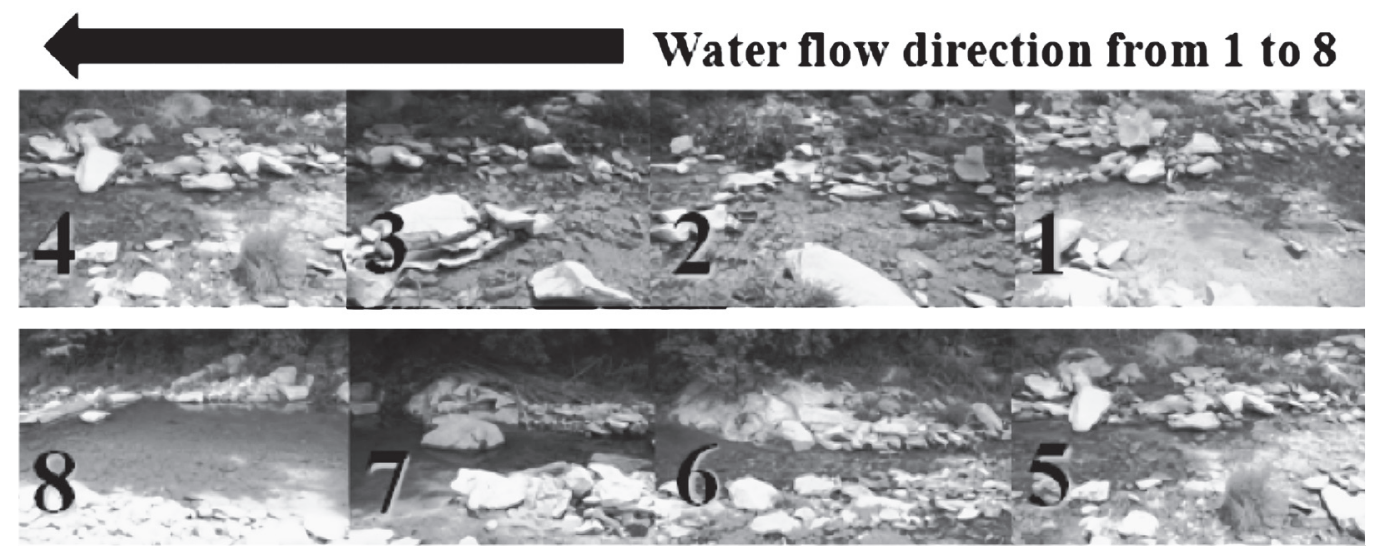

Fig. 4. Overview of the main habitat of Kichulchoia brevifasciata in Geumsan-myeon, Goheung-gun, Jeollanam-do, Korea. 


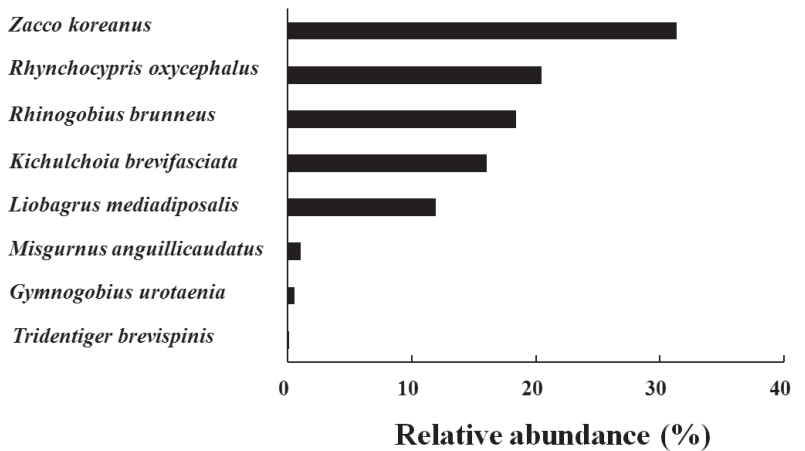

Fig. 6. Relative abundance of fishes collected from May 2006 to May 2007 (inclusive) in Geumsan-myeon, Goheung-gun, Jeollanam-do, Korea.

Table 3. Estimated population size following capture and recapture method of Kichulchoia brevifasciata in Geumsan-myeon, Goheung-gun, Jeollanam-do, Korea

\begin{tabular}{lc}
\hline Year, Month & Apr May 2007 \\
\hline Gross area of research site $\left(\mathrm{m}^{2}\right)$ & 156 \\
Total number of $\mathrm{1}^{\text {st }}$ captured individuals & 123 \\
Total number of $2^{\text {st }}$ captured individuals & 97 \\
Captured on both visits & 6 \\
Sampling intervals (days) & 15 \\
Expected population size (individuals) & 1735 \\
By catch rate $(\%)-1^{\text {st }}$ recapture & $1 \%$ \\
Density (population size $\left./ \mathrm{m}^{2}\right)$ & $11.1 / \mathrm{m}^{2}$ \\
\hline
\end{tabular}

gradually in May when $K$. brevifasciata showed enhanced activity and increased numbers. Although $Z$. koreanus, $K$. brevifasciata and L. mediadiposalis were observed in upper, mid-and downstream reaches, $R$. oxycephalus was restricted to upper and mid-stream sites, and $R$. brunneus and T. brevispinis to mid-and downstream sites.

\section{Estimation of population size}

A population size estimate (excluding juveniles) was conducted in April and May 2007 at the major upstream habitat (overall area $156 \mathrm{~m}^{2}$ ) (Table 3). Recaptured individuals (6) indicated a $1 \%$ recapture rate, the population at that site comprising 1735 adults at a density of 11.1 individuals per $\mathrm{m}^{2}$.

\section{DISCUSSION}

During the present study, Kichulchoia brevifasciata was found only in a small (about $4.5 \mathrm{~km}$ in length) stream on Geoguem Island (Fig. 1), being absent in other previously-reported habitats (Table 4).

Although Kim et al. (1994) confirmed the species' existence on Geumo Island (Fig. 1-C), Chae and Yoon (2007) reported that population had become extinct. Significantly, the small streams characterizing the previously-confirmed habitats (Fig. 2-A, B and C) were
Table 4. Occurrence of Kichulchoia brevifasciata at examined sites

\begin{tabular}{ccc}
\hline Localities & $\begin{array}{c}\text { (Kim and Lee, } \\
\text { 1995) }\end{array}$ & Present study \\
\hline A & present & absent \\
B & present & absent \\
C & present & absent (Also Chae and Yoon, 2007) \\
D & present & present
\end{tabular}

A: Yamak-li, Pungyang-myeon, Goheung-Gun, Jeollanam-do, Korea; B: Okang-li, Podu-myeon, Goheung-gun, Jeollanamdo, Korea; C: Nam-myeon, Yeosu-si, Jeollanam-do, Korea; D: Geumsan-myeon, Goheung-gun, Jeollanam-do, Korea

extremely fragile, being narrow with limited water flow, and subject to continuing disturbance by stream development and flood control. In addition, the stream beds had been altered due to an adjacent factory construction, discharge of sewage (Fig. 2-A and D). Also, the construction of a debris barrier (about $1 \mathrm{~km}$ in length) at upstream of Geoguem Island (Fig. 1-D) finished in January 2007 may have also been a contributory factor in a small stream. The conflict between human needs for water resources and environmental conservation is often significant, particularly in cases of subsequently reduced stream flow and compounded problems due to water contamination (Gasith, 1992; Gasith and Resh, 1999). Therefore, it is considered that even small modifications to the fragile habitats of $K$. brevifasciata had a significant impact on those habitats.

The ichthyofauna recorded in the main habitat on Geogeum Island (Fig. 2-D) was similar to that of Geumo Island (Fig. 2-C), including Misgurnus anguillicaudatus, Rhinogobius brunneus and Liobagrus mediadiposalis. However, the dominant species differed, being Zacco koreanus and Rhynchocypris oxycephalus on Geoguem Island, and R. brunneus on Guemo Island.

Although the population size of $K$. brevifasciata in the optimal habitat area was determined as 11.1 individuals per $\mathrm{m}^{2}$, it is probable that such a figure is misleading if applied to the entire stream, the actual overall population size being likely to be at much lower levels.

The preferred habit of $K$. brevifasciata, preferring gaps between flat pebbles on a gravel substrate is similar to that of Cobitis shikokuensis, which inhabits pebble dominant substrate with subsurface interstices under the shallow banks of clear water pools, rarely burrowing into the substrate. Accordingly, the recent extinctions of local populations of $K$. brevifasciata (Fig. 1-A,B and C) are considered to have resulted from habitat fragmentation and modification of the bed structure, similar to that reported for C. shikokuensis (Shizumu, 2002; Kawanish et al., 2010; Kawanish et al., 2011).

Despite the present habitat of $K$. brevifasciata on Geogeum Island (Fig. 1-D) still having high water quality and adequate conditions for the species, the likelihood of continuing human impact, such as stream bed 
modification and construction of flood control measures, input of factory waste and pollution is ever present. In addition, high organic matter input may lower species' abundance and influence fish growth, even in otherwise unpolluted regions (Angermeier and Karr, 1994). Continuing uncontrolled habitat modification on Geogeum Island by human activities may very likely result in the loss of the final known habitat of $K$. brevifasciata and the extinction of the species.

In spite of this, $K$. brevifasciata is not currently designated as an endangered species (Ministry of Environment, 2008). The impending permanent connection of Geogeum Island to the Korean mainland by construction of the bridge will complete in December 2011, thereby removing the difficulty of access to the habitat of $K$. brevifasciata, is also likely to accelerate habitat destruction. Therefore, it is urgent that $K$. brevifasciataas be designated as a special protected species in Korea and the habitat protected by the imposition of legal controls. Conservation activities are also essential for the re-establishment of optimum habitats and reintroductions of the species, with ongoing status assessments, in addition to the creation of conservation awareness in local residents.

\section{ACKNOWLEDGEMENTS}

All experiments complied with the current laws of the country in which they were performed. We would like to express special thanks to the students and graduating seniors of the Ichthyology Laboratory, Chonbuk National University for their valuable comments and assistance with the fieldwork. We are grateful to Dr. G.S.Hardy (Ngunguru, New Zealand) for careful comments for improving the manuscript, and to the Ministry of Education, Culture, Sports, Science \& Technology (MEXT), Japan for supporting its completion.

\section{REFERENCES}

Angermeier, P. L. and J. R. Karr 1994 Biological integrity versus biological diversity as policy directives: protecting biotic resources. Bio. Science, 44: 690-697

Chae, B. S. and H. N. Yoon 2007 Freshwater fish fauna of the Yeosu peninsula and Geumo Islands, Korea (in Korean with English summary). Korean J. Ichthyol., 19: 225-235

Chapman, D. G. 1951 Some properties of the hypergeometric dis- tribution with applications to zoological sample censuses. Univ. Calif. Public. Stat., 1: 131-60

Cummins, K. W. 1962 An evolution of some techniques for the collection and analysis of benthic samples with special emphasis on lotic waters. AM. Midl. Nat., 67: 477-504

Gasith, A. 1992 Conservation and management of the coastal streams of Israel: An assessment of stream status and prospect for rehabilitation. In Boon, P. J., P. Calow \& G. E. Petts (eds), "River Conservation and Management". John Wiley \& Sons Ltd. (New York) pp. 51-64

Gasith, A. and V. H. Resh 1999 Streams in mediterranan climates: abiotic and biotic responses to predictable seasonal events. Ann. Rev. Ecol. Syst., 30: 51-81

Kani, T 1944 Ecology of the aquatic insects inhabiting a mountain stream (in Japanese). In "Furukawa H (ed) Insects I" Kenkyusha, (Tokyo) pp. 171-317

Kawanishi, R., Y. Kudo and M. Inoue 2010 Habitat use by spinous loach (Cobitis shikokuensis) in southwestern Japan: importance of subsurface interstices. Ecol. Res., 25: 837-845

Kawanishi, R., M. Inoue, M. Takagi, Y. Miyake and T. Shimizu 2011 Habitat factors affecting the distribution and abundance of the spinous loach Cobitis shikokuensis in southwestern Japan. Ichthyol. Res., 58: 202-208

Kim, I. S., W. O. Lee and C. H. Youn 1994 Fish fauna of the Kumo Islands, Chollanam-do, Korea (in Korean with English summary). The Report of the KACN., 32: 193-209

Kim, I. S. and W. O. Lee 1995 Niwaella brevifasciata, a new cobitid fish (Cypriniformes: Cobitidae) with a revised key to the species of Niwaella. Ichthyol. Res., 42: 285-290

Kim, I. S. 1997 Illustrated encyclopedia of fauna \& flora of Korea (in Korean). Vol 37 Freshwater Fishes. Ministry of Education (Seoul), pp. 629

Kim, I. S. and E. J. Kim 2008 Karyotype of dwarf loach, Kichulchoia brevifasciata (Pisces: Cobitidae) from Korea. Korean J. Ichthyol., 20: 61-65

Kim, I. S. 2009 A review of the spined loaches, family Cobitidae (Cypriniformes) in Korea. Korean J. Ichthyol., 21(Suppl.): $7-28$

Kim, S. Y., I. S. Kim, K. Y. Jahng and M. H. Chang 2000 Molecular phylogeny of Korean loaches inferred from mitochondrial DNA cytochrome b sequence. Korean J. Ichthyol., 12(4): 223-229

Ministry of the environment 2008 Ecorea, Environmental review 2008, Korea. Misnistry of the Environment, (Republic of Korea). pp. 69-74

Seber, G. A. F. 1970 The effect of trap response on tag recapture estimates. Biometrics, 26: $13-22$

Shimizu, T. 2002 Life history of a Japanese spinous loach, Cobitis takatsuensis, in Shikoku Island (in Japanese with English summary). Japanese J. Ichthyol., 49(1): 33-40

Šlechtová, V., J. Bohlen and A. Perdices 2008 Molecular phylogeny of the freshwater fish family Cobitidae (Cypriniformes: Teleostei): Delimination of genera, mitochondrial introgression and evolution of sexual dimorphism. Mol. Phylogenet. Evol., 47: $812-831$ 